\title{
Futures in line? Occupational choice among migrant adult students in Sweden
}

\section{Magnus Dahlstedt \& Andreas Fejes}

To cite this article: Magnus Dahlstedt \& Andreas Fejes (2019) Futures in line? Occupational choice among migrant adult students in Sweden, International Journal of Lifelong Education, 38:1, 76-87, DOI: 10.1080/02601370.2018.1497719

To link to this article: https://doi.org/10.1080/02601370.2018.1497719

\section{(C) 2018 The Author(s). Published by Informa UK Limited, trading as Taylor \& Francis Group. \\ 曲 Published online: 09 Jul 2018.}

Submit your article to this journal

\section{山ll Article views: 291}

View Crossmark data $₫$ 


\title{
Futures in line? Occupational choice among migrant adult students in Sweden
}

\author{
Magnus Dahlstedt ${ }^{\mathrm{a}}$ and Andreas Fejes ${ }^{\mathrm{b}}$
}

aDepartment of Social and Welfare Studies, Linköping University, Linköping, Sweden; ${ }^{b}$ Department of Behavioral Sciences and Learning, Linköping University, Linköping, Sweden

\begin{abstract}
The aim of this article is to analyse the ways in which migration plays out in adult students' narratives about their occupational choice and future, focusing on three individual narratives of adult students with various experiences of migration to Sweden. Drawing on Sara Ahmed's conception of orientation, our results show how the adult students' narratives on their future occupations are formed on the basis of migration, pertaining to their particular experiences of being recognised as migrant Others. Among the three students, similar challenges emerge in terms of their claims for belonging. One the one hand, the students do claim belonging to the Swedish social community. On the other hand, they are - as 'migrants' - repeatedly reminded of their non-belonging to this community. In various ways, they feel out of place. Although migration, in the narratives, is not played out one and the same way, but in various ways, engagement in adult education as a means of finding a job appear as the main orientation guiding the futures of the adult students, as being an important way of finding a future and claim one's belonging to the Swedish social community.
\end{abstract}

\section{KEYWORDS}

Occupational choice; migration; orientation; belonging; narrative

\section{Introduction}

This article focuses on occupational choice among students enrolled in municipal adult education (MAE) in Sweden, and how these choices are formed in the context of migration. With the current migration patterns in Europe, and particularly the historically high number of refugees coming to Sweden and other member states of the European Union in the period 2015-2016, issues of migration and the inclusion of migrants have moved to the centre of political debate. In several of the member states of the European Union, exceptional policy measures have been taken in order to handle the so-called 'refugee crisis' - such as intensified border controls, the introduction of identity checks at specific checkpoints as well as within the borders of a country, and restrictive rules for the reception of asylum seekers. Such policy measures have also been taken in Sweden, which have drastically curtailed migrants' opportunities to enter the country.

In this context, adult education has risen to the top of the political agenda in Sweden. It has been proposed as a central tool for the inclusion of migrants into Swedish society, not least by providing the knowledge necessary to enter the labour market, as well as to live and manage as citizens (e.g. Ministry of Education, 2015). Those considered to be in need of a second chance 
through MAE have always had low levels of education. However, this group has changed over time. Previously, many of the students were born in Sweden, while today, a much higher proportion were born in another country (45 percent of all students compared to 20 percent during the early 1900s) (Fejes, Dahlstedt, Olson, \& Sandberg, 2018). Thus, MAE has very much become a second chance for those migrants who either have low levels of education or are in need of re-schooling in order to enter the labour market.

The aim of this article is to analyse the ways in which migration plays out in adult students' narratives about their occupational choices and futures. Drawing on Sara Ahmed's theory of orientation, we will show how adult students' narratives about their occupational futures are formed on the basis of migration, pertaining to particular experiences of being recognised as migrant Others. The article is structured as follows: first, the issue of migration and adult education in relation to the Swedish context is described, followed by the introduction of our analytical and methodological approach. Thirdly, we introduce the analysis by providing three illustrative examples: the narratives of Ana, Juan and Jane. Among the student narratives, similar challenges emerge in terms of their claims to belonging. One the one hand, the students do claim belonging to the Swedish social community. On the other hand, they are - as 'migrants' - repeatedly reminded of their non-belonging to this community. In various ways, they feel out of place. However, the main orientation for the students, albeit in different ways, is engagement in adult education as a means of finding a job. By finding a job, futures emerge that might make it possible for these students to claim belonging to the Swedish social community. We end the article with some concluding remarks.

\section{Migration, 'Swedish values' and adult education}

Sweden has for quite some time had an international reputation for having developed a welfare regime based on the principles of social equality, solidarity and democracy. Sweden also has an international reputation for its generous immigration policies as well as for its inclusion of migrants. However, as indicated by developments in the politics of welfare and integration over the last few decades, as well as research, this conceptualisation of an equal and inclusive Swedish model has been substantially challenged (Hübinette \& Lundström 2015; Schierup \& Ålund, 2011).

Already in the early 1990s, Allund and Schierup (1991) characterised the state of Swedish multiculturalism as quite paradoxical, highlighting the tension between citizenship in the formal sense (being a member of the community, in juridical terms) and citizenship in the substantive sense (in terms of societal living conditions). In spite of the ambitions to include migrants and make them full members of Swedish society, thereby enjoying the same formal rights as any Swedish citizen, the substantive societal living conditions of the included migrants did not match these ambitions. A range of studies have later highlighted similar tensions between ambitions and conditions in terms of citizenship rights, where racialised migrants in particular are positioned as second-class citizens - in the justice system (Diesen, 2005), politics (Bevelander \& Spång, 2017), in the educational system (Gruber, 2007), the labour market (Vesterberg, 2016) and in terms of housing (Ngeh, 2011).

Public discourse on multi-ethnic Sweden has become more and more polarised. On the one hand, there is still a desire to include migrants into Swedish society. On the other hand, public discourse has gradually become tougher, with an increasingly authoritarian character (Dahlstedt \& Neergaard, 2016; Schierup, Hansen, \& Castles, 2006). More recently, this has been exemplified by the growing popularity and electoral success of the right-wing populist party, the Swedish Democrats, with an explicit focus on both polarising and politicising the 'problems' of migration and multicultural Sweden (Berggren \& Neergaard, 2015; Norocel, 2017).

A focus on the 'problems' of migration and integration has been further accentuated in recent years, particularly in the aftermath of the 'refugee crisis' of 2015, when policies were adopted in order to 'secure' the national borders and decrease migration (Prop. 2015/16:174). In 2016, the 
Swedish parliament passed interim 3-year legislation concerning migration, including, among other proposals, the following:

- The abolishing of minimum state subsidies for applicants with legally binding rejections.

- The mobilisation of the police to implement the swift expulsion of applicants with legally binding rejections.

- The legal application of temporary residence permits - usually for 13 months.

- The linking of economic self-sufficiency to permanent residence permits and family reunification.

In 2017, Schierup, Ålund and Neergaard (2017: 31) described the state of multi-ethnic Sweden as follows: 'The current political trajectory in Sweden as well as across most of Europe indicated a possible merger of the neoliberal project of exploitative racism with the extreme right's exclusionary racism'. Although explicitly repressive policy measures targeting racialised migrants have been promoted by radical right-wing forces, such policy measures have gradually become normalised. These measures particularly target 'Muslims', a category portrayed as deviant and threatening the 'core values' of Swedish society (Dahlstedt, 2018; Eliassi, 2017). Thus, in Sweden, as in several other European countries, the more established political parties have gradually redefined their view of rights and obligations, whereby sharper demands have been put on migrants to adapt to the norms and values of the Swedish majority society characterised as specifically 'Swedish values' (Norocel, 2017; Strömbäck, Andersson, \& Nedlund, 2017). Here, the presence and concentration of racialised migrants in particular areas throughout Sweden has been used as a means for legitimising more stringent requirements and the introduction of various repressive measures aimed at the migrants and the areas they inhabit (cf. Schierup \& Ålund, 2011; Sernhede, Thörn, \& Thörn, 2016).

\section{Adult education in Sweden}

The adult education system in Sweden is unique, providing free education for adults and the opportunity to take courses providing eligibility to apply for higher education, courses preparing for specific occupations, and courses preparing for life as a citizen more generally. Financed by the state and municipalities, adult education is delivered by welfare institutions such as MAE, which includes Swedish for migrants (SFI), as well as by civil society institutions such as folk high schools and study associations. Adult and popular education has traditionally been a central governmental tool for contributing to the adult population's opportunities to increase their employability as well as their inclusion in society as democratic citizens (see e.g. Fejes, 2015, 2016; Fejes et al., 2018). The big difference between MAE (including SFI) and popular education institutions is that the former is part of the formal education system governed by a statedetermined curriculum, while the latter is part of civil society, and can be described as 'free' and 'voluntary', in terms of both participation and organisation.

Overall, it appears that the adult education system in Sweden, in general, has been quite successful in terms of increasing adults' knowledge and competencies. While Sweden ranks low in the PISA study (measuring students' knowledge in compulsory school), the country was ranked near the top in the first round of the PIAAC study 2008-2013 (the OECD study on adults' skills), especially in terms of adults' problem-solving skills (Statistics Sweden, 2013). The PIAAC study also illustrates that there are great differences in Sweden between those with high and low skills. Among those with low skills, we find poorly educated Swedes and migrants. This situation, in combination with the migration flows of recent years, raises serious challenges for adult education to address. How can adult education contribute to social inclusion within the multicultural reality in today's age of migration? Previous research indicates that the 'second chance' provided by adult education in Sweden does have some positive effects, not least for migrants born outside of the 
Nordic countries (Nordlund, Bonfanti, \& Strandh, 2013). However, what is not taken into account is the question of how migrants, in their micro-context of everyday life, reason about participation in adult education as a means of pursuing their dreams for the future. In this article, we address this latter specific issue; that is, in what ways does migration play out in adult students' narratives about their occupational choices and dreams of the future?

\section{Theoretical approach}

In this article, we draw on Sara Ahmed's phenomenologically inspired theory of orientation. The concept of orientation draws attention to the ways in which we all come to know where we are in the world, as we turn in different directions, towards certain objects and subjects. Some of these may appear near, while others appear distant. How we come to orient ourselves towards certain objects and subjects, located in time and space, is an effect of history and not a matter of something 'ordinary': 'Bodies tend toward some objects more than others, given their tendencies. These tendencies are not ordinary; they are effects of the repetition of "tending toward"' (Ahmed 2006: 553). Ahmed refers to such 'tending toward' certain objects and subjects as the creation of lines. To 'be in line', according to Ahmed, means to follow the established norms and conventions (i.e. inhabiting the familiar, feeling at home and at ease). The opposite - that is, being out of line means being recognised as somebody who is out of place, as not belonging - a stranger.

...the politics of who gets to be at home, who gets to inhabit spaces, as spaces that are inhabitable for some bodies and not others, insofar as they extend the surfaces of some bodies and not others. (Ahmed, 2007: 162)

Here, Ahmed draws on thoughts from a post-colonial tradition, not least as developed by Fanon (1952/2008), relating the concept of orientation to issues of whiteness and the histories of colonialism. By deploying such an argument, she illustrates how certain bodies, marked as nonwhite, come into being as not belonging: "Whiteness could be described as an ongoing and unfinished history, which orientates bodies in specific directions, affecting how they "take up" space' (Ahmed, 2007: 150). Being in line or being out of place is thus not only a matter of being in a certain space, but also of being in a certain time: 'bodies are shaped by histories of colonialism, which makes the world "white", a world that is inherited, or which already given before the point of an individual's arrival' (Ahmed, 2007: 153).

Accordingly, Ahmed's understanding of orientation and the ways in which bodies are oriented towards objects and subjects in the world provides a conceptual framework for analysing not only how bodies are oriented towards the world of today, but also in relation to the past as well as the future. 'Even when orientations seem to be about which way we are facing in the present, they also point us toward the future', Ahmed (2006: 554) emphasises, and 'the hope of changing directions is always that we do not know where some paths may take us'.

\section{Methodological considerations}

Guided by Ahmed's conception of orientation, the focus of the analysis presented in this article is directed towards the orientations described in adult students' narratives about their occupational choices and futures. A particular emphasis is put on the ways in which these orientations are related to particular experiences of migration.

In the analysis, we draw on interviews conducted within a larger research project on citizenship formation within and beyond adult and popular education (see Fejes et al., 2018). This project engaged in the elicitation of student narratives about what it means to be a citizen - in a broad sense - and what they themselves say they do 'as citizens', within as well as beyond their studies (i.e. 'their doings of citizenship') (cf. Nicoll, Fejes, Olson, Dahlstedt, \& Biesta, 2013). More specifically, we draw on field study data gathered at a school for MAE in a large city in Sweden. The data consists of observations in the classroom as well as interviews with a total of 
37 students from different backgrounds. The school was chosen due to its size, providing a range of courses with potential data access, as well as a site where access was granted. Two social science teachers in the school were followed in their work more widely, as well as their teaching of social science courses to students more specifically. In each class, students were selected for interviews based on a convenience sample (i.e. those who willingly agreed to be interviewed). Of these students, 21 were women and 16 were men. Thirteen of the students had migrated to Sweden from a range of different countries - in Europe (e.g. Spain and Hungary) as well as outside Europe (e.g. Syria, Iran, Lebanon and the USA). Thus, in terms of gender as well as migration, our sample represents the pattern of participation in MAE in Sweden, where more than 40 percent are migrants, and the majority are women (Swedish National Agency for Education, 2015).

The interviews focused on questions about what students considered to be of importance regarding education for their presumptive occupational futures, both inside and outside adult education. Among other things, the interviewees spoke about why they had taken up adult education and about their aspirations for the future. All interviews were transcribed verbatim and analysed using the software program Nvivo. The analysis was conducted in three steps. Firstly, an initial qualitative thematic analysis of the data was made, with a focus on the different ways of describing participation in adult education, dreams about the future, and occupational choices. On the basis of this initial analysis, we found that the 13 migrant students' ways of describing participation in adult education, the future and occupational choices were, in different ways, interwoven with their experiences of migration and that, not least, non-belonging to the national community of Swedish society was a recurring topic.

Secondly, we conducted a more focused thematic analysis of interviews with migrant students, concentrating on their ways of talking about migration, their belonging to Swedish society, the future and occupational choices. In this analysis, the following recurring topics were found: the students' ways of talking about their experiences of migration, in the past as well as today; the ways in which the students talk about their desire to belong in Sweden, at the same time as they are repeatedly reminded of their non-belonging; and the ways in which these narratives relate to the students' talk about the future. In the transcripts, there were commonalities in all of these topics, but also differences.

In a third step, we selected three of these interviews as illustrative examples of our wider analysis - those with Ana, Juan and Jane. The interviews represent three different migration trajectories and educational aspirations. Although the stories told by these three students are unique and articulate quite specific (and different) descriptions, there are also similarities, not least concerning the students' feelings of being out of place. Drawing on Ahmed's theory of orientation, in the following we will introduce these three narratives with a focus on each student's orientation into the future in terms of occupational choice, and the ways in which these orientations relate to migration.

\section{Ana's story}

Ana was born in Hungary. Her father is Roma, and her mother is Hungarian. She came to Sweden when she was 11 years old. Ana has been a Swedish citizen for many years, but she doesn't really feel herself to belong to the Swedish social community. 'I'm not Swedish, so to speak. I became a Swedish citizen by coming here'. As described in her narrative, living in Sweden has its problems. In Sweden, there is both prejudice and discrimination. Ana describes her childhood as a time when she was treated as different, as being Roma:

I was the only girl in the entire school with a foreign background. [...] It was really hard to be at school [...] I spoke English at school as I didn't know any Swedish at all [...] I felt that, okay, now I'm in Sweden, now I can be as open as I want to be, so I told a girl that my dad was Roma and such. Then she told me that I shouldn't tell anyone else in school. [...] So, I didn't tell anyone else. 
Here, Ana describes the challenge of learning how to orient herself in relation to others' conceptions of Roma. Her strategy to become normal was simply to avoid telling others about her Roma background (i.e. trying to slip away into the background). When talking about her belonging, Ana distances herself from 'typical Roma people'. 'I was not raised as a typical Roma girl, so to speak. You can see if a person is Roma. But me, I don't think people can see that I'm Roma'. The 'typical Roma person' is described as self-excluding, passive, as someone who does not wish to work and who uses the system: 'Most of the time, among Roma people, they use the Swedish system. [...] They don't like to work. And that's how it has been for generations'.

In relation to this characterisation of the 'typical Roma person', Ana positions herself as being in line (i.e. as well adapted to Swedish society). 'I feel that I've adapted quite well to society'. Her biggest problem though, is to be conflated with those who do not belong and who do not wish to adapt (i.e. as being out of place).

I'm bunched together with those who do not wish to live as Swedish citizens, and it's I who have to suffer from it, and I don't want my children to suffer from it.

Talking about belonging, Ana also makes a distinction between being a Swedish citizen formally, having certain rights and duties, and not being born in Sweden. Even though she herself was not born in Sweden and is not seen as fully Swedish, she is still - formally - a Swedish citizen, and as such she is a bearer of certain rights. As a citizen it is also, as she points out, necessary to follow the laws and regulations, to fulfil one's duties (i.e. to be in line).

If you live in Swedish society, you follow their laws, and then you are granted the same rights. There are some who use Swedish society, who wish to have the same rights as a Swede does, at the same time as they do not really follow the laws.

Here, belonging is constructed through difference. Ana does not belong to the category 'of Swedish origin'. Neither does she belong to the category of those who use the Swedish system. She is somewhere in the middle - neither 'We' nor 'Them'. Thus, Roma and Swedes are constructed as homogeneous, and mutually exclusive, collectives, with herself in-between. The problem is, once again, that some people demand their rights as citizens without fulfilling their duties. Thus, she argues that people immigrating to Sweden need to 'pitch in more', show gratitude and earn their rights as citizens.

I really believe that they should pitch in more than a Swede, because a Swede is always a Swede. [...] Show gratitude, thank you so much for letting me live here and be part of Swedish society.

The relationship between 'Swedes' and 'immigrants' that appears in Ana's narrative is explicitly hierarchical. 'A Swede is always a Swede', and always has the right to place demands on those who have immigrated.

Education, and especially adult education, is assigned great importance in Ana's narrative, both in the present and in her orientation towards the future. Education is a way for her to deal with issues of belonging to Swedish society, today as well as in the future: 'You feel that you become a bit more part of Swedish society when you go to school and study'. In Ana's narrative, education is described as an opportunity as well as a duty, making it possible to belong and to make a contribution to society. By engaging in education, you take responsibility and do not become a burden to society: 'As a citizen, I believe it's important to get an education and get a job in order to contribute to society'. Once again, Ana distances herself from other 'migrants', whom she describes as not making active choices in order to educate themselves and get a job. Rather, they 'come here, and just sit there getting social security money and using Swedish society'.

Ana tells us that she applied for adult education as a step towards becoming a social worker. Thus, her occupational choice is part of her orientation, her desire to adapt to the established norms and conventions of Swedish society, not least by contributing to society through her work, specifically in an occupation which is about helping others: 'I want to help people... I want to 
work with people and I want to help them and contribute to society by helping them'. Once again, Ana makes a distinction between us and them, where she, through her occupational choice, her orientation to the future, wishes to become part of the Swedish we, by helping others to do the same. Her entry ticket to the community is, thus, by actively contributing and not being passive. By becoming a social worker in the future, this is also exactly what she wishes to do, by helping others and being a role model - and as such getting others to follow her own orientation towards inclusion in society.

During my 24 years, I have always been a person who has listened, I'm not the one who asks people, but the person who people come to, and unload their problems. I love it, I love to listen, I love to listen to other people's problems and comment and help them based on my experiences and connect my experience to their problems. To tell them that that's how I did it or how my parents did it, so you can try doing it in that way.

In Ana's narrative about her occupational choice, the present is related to the future as well as to the past. Her occupational choice is made in the present, with a direction into the future, but is also part of her past, being described as the result of her personal traits and specific experiences. In her forthcoming occupational role, she construes herself as helping others and acting as a role model, as someone from whom others can learn, in order for them also to come in line with the current norms and conventions.

In sum, for Ana, adult education becomes a site that gives her a second chance, where she has the potential to realise her dreams for the future (i.e. to educate herself in MAE as a way to enter higher education and become a social worker). In doing so, her hope is thus to become included in society as a 'full' citizen.

\section{Juan's story}

Juan is in his 20s. He was born in Sweden, but has three different citizenships - Swedish, Chilean and Spanish. His parents moved from Chile in the 1980s. He describes how he grew up in 'a very segregated area' in the city. Growing up in such an area was the basis for his experience of, as he describes it, 'not feeling Swedish or feeling part of society', something he can still relate to when visiting the area where he grew up, despite not living there any more: 'You still don't see Swedish people with Swedish parents there'. As he grew up, he changed school, from the school located in the neighbourhood where he lived, to a 'nicer school', located in the adjacent municipality. 'There I could see how things could be very different, there were almost only Swedish children with Swedish parents'. In school, Juan came into contact with quite different norms and conventions, as compared to those he was used to, which made him feel different, out of place. Thus, he became an 'immigrant', a stranger, despite being born in Sweden.

There were different norms, it was another culture in school... You should dress in a specific way. I came with my Nikes, my soft trousers, my Nike jacket, while all the others had denim shirts. So, it was very different, but you could adapt quite quickly. But it's only 10 minutes by bus, and still the differences are so huge. And they have a lot of prejudices. They see me as an immigrant, despite being born here, and it was a lot of 'yes, you're good, but...'

It was not only Juan who felt different during his early years. So did his parents, and particularly his father. In their case, it wasn't school where they felt different, but rather at work.

My dad, he worked in the industries here in the city, and he never felt that he belonged to society in any way. He felt discriminated against by other people at work, as soon as he left the building, people looked at him suspiciously, and maybe that wasn't always the case, but he never felt that he belonged to society.

The feeling of non-belonging to Swedish society made the parents decide to move from Sweden to Spain. Juan moved with his parents, became a Spanish citizen and began upper secondary school. In his narrative, Juan describes his time in Spain as hard and bewildering. Once again, he felt that 
he was different, not in line: 'It was really an identity crisis'. Not least, the schools were organised in a totally different way compared to what he was used to: 'It's a very different system over there. It's very conservative'. The feeling of being out of place made him wish to go back to Sweden: 'the thought has always been to come back here'. After completing upper secondary school, Juan chose to leave his parents, in order to move back to Sweden, particularly to continue studying. Thus, for Juan, his educational trajectory was strongly related to migration.

As with Ana, his ambition is to become a social worker. In order to achieve this goal, he has to study in adult education. For Juan, his occupational choice connects up with a desire to contribute to young people's development, because he construes himself as having important experiences that he wants to share with young people: 'I know what they're feeling. I've been there and some of them want to continue studying, some don't give a damn'. As in Ana's narrative, there is a relation between the present, the past and the future. In order to contribute to young people's development, Juan has also, for a few years now and in parallel with his studies, been engaged as a sponsor for children in other countries as well as engaged in home-work support.

When he describes his occupational choice, it becomes clear that it was shaped through his experience of the years living in Spain. While Juan describes his years in Spain as hard and bewildering, he also describes that time in quite a romantic fashion. Not least, Spain is described as a much more open country than Sweden: 'Everyone is so welcoming. And I don't know if it's part of the culture, but they're more hospitable than people in Sweden'. His experiences in Spain made Juan see Sweden in a new light, when he eventually moved back. The desire to engage and help - especially concerning young people who are having a tough time - grew stronger, and this also came to inform his occupational choice.

It's not a big deal, you take it for granted that you should help. If you go to Spain and live in a neighbourhood, there will be people who will knock on your door or say: 'Here I am, if you need help, please let me know'. I've been living here for two years now and I barely know... it's a big difference... there will always be people who might need a bit of extra help, but you have the view that you don't give a damn about others, you blame... You just want to be with your family here and now, and then it's very easy to close the borders....

During his time in Spain, Juan came to see the value, as a citizen, of helping others, something he describes as more or less taken for granted in Spain, but which is not at all taken for granted in Sweden. His experiences in Spain made him see Sweden as more individualistic than he did previously: 'You don't give a damn about others'. At the same time, he points out that citizens cannot only put responsibility in the hands of others. Citizens also need to take responsibly for themselves: 'I can't just take it for granted that society is going to help all the time. I also have to contribute'.

In sum, Juan dreams of a future in which he becomes a social worker who can help others. In order to reach these goals, he has to study MAE in order to become eligible to apply for a social worker course at the university.

\section{Jane's story}

Jane moved from the USA to Sweden 2 years ago, in order to live with her boyfriend who was born in Sweden. She was born in Germany, and as her parents were working in the US army, she moved around a lot while she was growing up.

I was born in Germany. Both my parents were in the army in Germany, when the wall came down during the '80s. Then we moved to Florida, then to Marilyn, then back to Florida, then up to Maine, then to New York, Texas, and....

The construction of the Swedish welfare and education system was an important reason for her and her boyfriend to choose to settle down in Sweden. Thus, as she explains in her narrative, her orientation towards education and its relation to future occupational life, as in the cases of Ana 
and Juan, is strongly related to migration. 'The system of student loans in the US is very different from here, as you have to pay tuition fees, and then you have to support yourself, so the loans become much higher'. At the same time, Jane describes herself as feeling much more ideologically at home in Sweden than in the USA: 'I'm more inclined to agree with the left wing of Swedish politics rather than the US. It's a bit of a collision with my family'. In this sense, Sweden feels like home to Jane. Her view of politics has been strongly shaped by the experiences she had when growing up, particularly when her family found itself in great financial problems due to her becoming ill and in need of what turned out to be very costly surgery.

If you're sick and need Medicare, you need a lot of money, otherwise you had to just stay at home and be sick. I had surgery when I was little, and my mum needed to pay 85 percent of the costs of the surgery, and it ended up being 300000 dollars. I think they're still paying for it.

In Jane's way of talking about her choice of future country of residence, this experience plays a significant role. 'I don't want to raise my children in a country where you have to pay a lot of money in order to educate yourself, she emphasises. Thus, she and her boyfriend decided to move to Sweden. Even though Jane describes herself as politically belonging to Sweden, there are other aspects of her life in Sweden which she describes as less pleasant, making her feel that she does not quite belong. She describes her meeting with Sweden as a 'cultural shock' which still might be a challenge.

Jane: People are not very nice. That's what I first noticed, that no one wanted to speak to me, no one wanted to look me in the eye, but later on I got to know that it's because people wanted to be polite. They don't look you in the eye, they don't say 'oops, you dropped that', or something to be polite and they don't want you to feel embarrassed. That's a few different culture shocks.

Interviewer: How is it to live here now?

Jane: Sometimes a bit uncomfortable. I was shy to begin with, at the same time as I was social, I like to talk with people, and maybe when I'm standing in a queue in a store I used to talk to the person next to me or in front of me, but if I try to do that here it becomes strange, they just look at me or maybe ignore me and think I'm strange.

Interviewer: Is it the same where you live, you don't have any contact with your neighbours and such? Jane: No. We say hello to each other, but that's about it.

Interviewer: And that's also different?

Jane: It feels a bit more isolated here.

Such experiences of feeling strange and being different have meant that Jane does not feel really at home in Sweden, or in the USA: 'I don't feel like I belong in Sweden, but neither do I feel that I belong in the US'. Maybe not today. But the situation might be different in the future: 'But maybe in five to ten years, I might feel more Swedish or more American'.

In Jane's narrative, adult education is described as a first step on the way to studying at university, where she plans to train as a computer engineer: 'Hopefully, I will be admitted to the programme this June. I need to study the technical basic year first. And then at university, where I will continue on the computer engineering programme'. In the future, Jane wants to work with computers, hopefully in a private company: 'Hopefully, I'll finish my studies and work for some company. I'm not quite sure where I want to work, but I'm very into computers'. As in the cases of Ana and Juan, adult education for Jane appears to be an important strategy for becoming who they want to be in the future. However, compared to Ana and Juan, for Jane, participation in adult education appears to be a right rather than a duty. For Jane, her choice of participating in adult education is more a matter of using her rights as a citizen, while this choice for Ana and Juan appears to be more a matter of performing their duty as citizens, by contributing to society. In all three narratives, certain lines of orientation are shaped in the name of migration, where the past, present and future merge in the adult students' narratives about their occupational choices. For Ana and Juan, their occupational choice is described as part of a desire to contribute and to help others, while for Jane, it is described as part of a desire to follow and realise her dreams. 
In sum, Jane's occupational dream for the future is to become a computer engineer, and thus she first has to study in MAE, in order to become eligible to apply for higher education.

\section{Discussion}

In this article, we have focused on the ways in which migration plays out in adult students' narratives about their occupational choices and dreams for the future. Drawing on Ahmed's $(2006,2007)$ theory of orientation, we have illustrated how the past, present and future merge in student narratives, in which migration plays an important role. Similar challenges emerge in terms of belonging to the Swedish social community. While the students claim their belonging to this community, they are - as 'migrants' - repeatedly reminded of their non-belonging. In various ways, they describe how they feel out of place. On the basis of such experiences, all three students outline specific orientations towards the future, where engagement in adult education as a means of finding a job appears as an important line of orientation guiding the future, as a way of finding a future and claiming one's belonging. However, their specific trajectories are also different in some respects.

Ana describes herself as quite occupied with being in line of adapting to established norms and conventions. Accordingly, she has struggled to keep silent about her Roma belonging, in order to appear as a 'normal Swede'. As a way of claiming her belonging to the Swedish community, Ana repeatedly distinguishes herself from the Roma. However, at the same time, her belonging in terms of having been born abroad, to foreign-born parents, makes her feel constantly somewhat out of place. She may formally be a Swedish citizen, but she concludes that she can never become a Swede. Ana's conceptualisation of work and occupational choice reflects this troublesome sense of belonging. By engaging in adult education, her hope is to study at university in order to become a social worker. In such an occupational role, opportunities to contribute to society would emerge, she tells us; thus, she would be in line, in contrast to those who choose not to contribute to society.

Like Ana, Juan describes experiences of being out of place, in his case in both Sweden and Spain, where he moved together with his parents as a child. As in Ana's narrative, the present, the past and the future are intimately related in Juan's narrative about his orientation towards education and his occupational choice. In this narrative, he describes his experiences of migration as being crucial. Juan describes how, while living in Spain, he came to see the value of helping others. This made him see Sweden in a different way, but it also stimulated him to engage in further education in order to realise his dream of a future career as a social worker, through which he would like to contribute to young people's development. Thus, for Juan, as well as for Ana, participation in adult education appears as a path enabling him further to contribute to society by helping others.

Like Ana and Juan, Jane has experiences of migration and she describes these experiences in similar terms. Even though she describes feeling at home in terms of political belonging, she also describes feelings of non-belonging - in Sweden as well as in the USA, the country where her parents were born and where she spent most of her childhood. As for Ana and Juan, adult education is a first step for Jane on the way to further education, in her case, to become a computer engineer. In Jane's narrative about her orientation towards education and occupational choice, migration plays a crucial part. Actually, it was the generous conditions and opportunities for adult education offered in Sweden that led to her and her husband choosing Sweden as their future country of residence. However, in contrast to Ana and Juan, Jane sees participation in adult education not as a duty, but rather as a right. Jane describes her choice of participating in adult education more as a matter of using her rights as a citizen. While Ana and Juan describe their occupational choices as part of their desire to contribute and to help others, Jane describes it rather as part of her desire to follow and realise her own dreams. By engaging in MAE, she can then apply to university in order to become a computer engineer. 
In a way, these individual narratives tell us something about some of the conditions and challenges regarding belonging in contemporary Sweden, as well as in contemporary Europe, with implications for adult education. The narratives about belonging and claims of belonging told by these students reflect the broader renegotiations of belonging taking place in the aftermath of the so-called 'refugee crisis' in Europe post-2015. Overall, the narratives analysed in this article address the crucial question of who is included in the social community and who should be left out. This particular question is also at the very centre of the political debate in Europe today. On the one hand, there are strong arguments about the 'death of multiculturalism', and the demands, including from Sweden, for new disciplinary means to exclude targeted migrants - particularly Muslims (Dahlstedt \& Neergaard, 2016; Norocel, 2017). On the other hand, in Sweden as well as in other European countries, claims have been made for the development of a new and more inclusive social community which will expand the rights of citizens by accommodating those who have previously been excluded (Isin, 2012; Nordling, 2017).

This very question of belonging in an era of international migration also relates to the potential of adult education to help in developing a more inclusive societal community, a community that also includes those who are currently perceived as strangers and outsiders within, even though these strangers may see and feel themselves at home and claim their belonging as insiders. As the analysis illustrates, for these three students, as well as for the rest of the students interviewed in the project, MAE emerges as a space that might be able to provide opportunities to realise their future dreams (cf. Sandberg, Fejes, Dahlstedt, \& Olson, 2016). In this specific case, such dreams, for two of the students, concern giving something back to society, while for the third, the dream is rather an issue of the right to realise oneself. A second question thus emerges: how can adult education de facto contribute to such realisations? What we have been able to illustrate is that there are dreams here and now, but the data does not allow us to say anything about the outcome of these students' participation in MAE. The key question here is: into what sort of social community should migrant students be included? In line with Ahmed's argument, such an inclusive community may be understood as being formed in negotiations and dialogues in the world of today, out of the conditions of today, but also in relation to the past, as well as to the future.

The differences between us necessitate the dialogue, rather than disallow it - a dialogue must take place, precisely because we do not speak the same language. The 'we' of such a collective politics is what must be worked for, rather than being the foundation of our collective work. [...] It is a 'we' that can be embraced only through a willingness to struggle with and for others who are faced in the present, a facing that is indebted to a past that cannot be left behind, as well as an openness to the future, as the promise and hope of what we might yet become (Ahmed, 2002: 570f).

The question is - still - where are the boundaries to be drawn for what and who should be allowed into the community of the inside? Who shall have the opportunities to belong to the inside and who shall be left on the outside? On what core values shall the community of the inside be based and who shall be able to define these values? All of these questions concern not only the present, but also the future. What futures are made possible according to today's conceptions of belonging? Who will be part of these futures - and in what way? And what role does adult education play in such an endeavour?

\section{Disclosure statement}

No potential conflict of interest was reported by the authors.

\section{References}

Ahmed, S. (2002). This other and other others. Economy and Society, 31(4), 558-572.

Ahmed, S. (2006). Orientations. GLQ: A Journal of Gay and Lesbian Studies, 12(4), 543-574.

Ahmed, S. (2007). A phenomenology of whiteness. Feminist Studies, 8(2), 149-168. 
Ålund, A., \& Schierup, C.-U. (1991). Paradoxes of multiculturalism. Aldersholt: Avebury.

Berggren, E., \& Neergaard, A. (2015). Populism. In M. Dahlstedt \& A. Neergaard (Eds.), International migration and ethnic relations. London: Routledge.

Bevelander, P., \& Spång, M. (eds.). (2017). Valdeltagande och representation. Stockholm: Delmi.

Dahlstedt, M. (2018). Förortsdrömmar. Linköping: Linköping University Press.

Dahlstedt, M., \& Neergaard, A. (2016). Crisis of solidarity? Critical Sociology. doi:10.1177/0896920516675204

Diesen, C. (2005). Likhet inför lagen. Stockholm: Natur och kultur.

Eliassi, B. (2017). Conceptions of immigrant integration and racism among social workers in sweden. Journal of Progressive Human Services, 28(1), 6-35.

Fanon, F. (1952/2008). Black skin, white masks. New York: Grove Press.

Fejes, A. (2015). Kortutbildade och vuxenutbildning. Stockholm: Stockholms stad.

Fejes, A. (2016). Vuxenutbildningens utmaningar i migrationens tidevarv. In B. Kindenberg (Ed.), Flera språk, flera resurser. Stockholm: Liber.

Fejes, A., Dahlstedt, M., Olson, M., \& Sandberg, F. (2018). Adult education and the formation of citizens. London: Routledge.

Gruber, S. (2007). Skolan gör skillnad. Linköping: Linköping University.

Hübinette, T., \& Lundström, C. (2015). Swedish whiteness and white melancholia. In V. Watson, D. HowardWagner \& L. Spanierman (Eds.), Unveiling whiteness in the 21st century. Lexington: Lanham.

Isin, E. F. (ed.). (2012). Citizens without frontiers. London: Continuum.

Ministry of Education. (2015). Ökad individanpassning. Stockholm: Author.

Ngeh, J. (2011). Conflict, marginalisation and transformation. Umeå: Umeå University.

Nicoll, K., Fejes, A., Olson, M., Dahlstedt, M., \& Biesta, G. (2013). Opening discourses of citizenship education. Journal of Education Policy, 28, 828-846.

Nordling, V. (2017). Destabilising citizenship practices. Lund: Lund University.

Nordlund, M., Bonfanti, S., \& Strandh, M. (2013). Second chance education matters! Income trajectories of poorly educated non-Nordics in Sweden. Journal of Education and Work, 28(5), 1-23.

Norocel, C. (2017). Åkesson at Almedalen. NORA: Nordic Journal of Feminist and Gender Research, 25(2), 91-106.

Prop. 2015/16:174, 'Förslag om att tillfälligt begränsa möjligheten att få uppehållstillstånd i Sverige', Government Offices.

Sandberg, F., Fejes, A., Dahlstedt, M., \& Olson, M. (2016). Adult education as a heterotopia of deviation. Adult Education Quarterly, 66(2), 103-119.

Schierup, C.-U., Ålund, A., \& Neergaard, A. (2017). Reimagineering the nation. In A. Ålund, C-U. Schierup \& A. Neergaard (Eds.), Reimagineering the nation. Frankfurt am Main: Peter Lang.

Schierup, C.-U., \& Ålund, A. (2011). The end of Swedish exceptionalism? Race \& Class, 53(1), 45-64.

Schierup, C.-U., Hansen, P., \& Castles, S. (2006). Migration, citizenship and the european welfare state. Oxford: Oxford University Press.

Sernhede, O., Thörn, C., \& Thörn, H. (2016). The Stockholm uprising in context. In M. Mayer, C. Thörn \& H. Thörn (Eds.), Urban uprisings. Basingstoke: Palgrave Macmillan.

Statistics Sweden. (2013). Den internationella undersökningen av vuxnas färdigheter. Örebro: SCB.

Strömbäck, J., Andersson, F., \& Nedlund, E. (2017). Invandring i medierna. Stockholm: Delmi.

Swedish National Agency for Education. (2015). Komvux - Elever och kursdeltagare riksnivå. http://www.skolver ket.se/statistik-och-utvardering/statistik-i-tabeller/komvux/elever-och-kursdeltagare [accessed 2016-09-07].

Vesterberg, V. (2016). Ethnicizing employability. Linköping: Linköping University. 